\title{
Gyula - város a határon A központi funkciók határon átnyúló hatása
}

\author{
Gyula - a small town in the border zone \\ within a cross-border urban region
}

\author{
NAGY GÁBOR
}

KULCSSZAVAK: határkutatás, funkcionális városrégió, határon átnyúló kapcsolatok, a határ változó jelentése, magyar-román együttmúködés

ABSZTRAKT: A Nemzeti Innovációs Hivatal által támogatott kutatás keretében 2009től kezdődően az MTA RKK Békéscsabai Osztálya és a Településkutató Osztály (Budapest) munkatársai komplex vizsgálatot indítottak a határon átnyúló várostérségek témakörében.

A kutatás föbb csomópontjai a következők voltak:

- a városrégió megjelenése az európai és hazai területi kutatásokban és politikákban;

- a városrégiók lehatárolásának módszertani kérdései, figyelembe véve, hogy az eredményeket a felsőoktatásban is szeretnénk alkalmazni;

- terepi felmérésekkel feltárni a magyar határon átnyúló várostérségek kialakulásának, fejlődésének mozgatórugóit, szakaszait, a határok átalakulásának fázisait.

A tanulmányban szereplő Gyulán - az említett terepmunka mellett - elemeztük a város fejlesztési dokumentumait, értékeltük a határ menti együttmúködési forrásért benyújtott pályázatokat, áttekintettük a megvalósult fejlesztésekhez kapcsolódó korábbi kérdőívezések eredményeit és a helyi sajtót, továbbá strukturált interjúkat készítettünk a kulcsszereplőkkel. (Helyben 45, kontrollként pedig a romániai oldalon - zömmel Nagyváradon és Aradon - 25 interjút vettünk fel.)

A kutatás során tapasztalt térfolyamatok erős egyoldalúságoł mutattak Gyula város, illetve a román oldalon elterülő községek viszonylatában. A magyar oldalról történő átmozgás döntően nem a határ közvetlen közelében fekvő kistelepülésekre irányul (kivéve talán Nagyszalontát), hanem erősebben a határhoz közeli partiumi nagyvárosokba - elsődlegesen Nagyváradra és Aradra -, illetve Erdély belső, magyarlakta területei felé. Ezzel szemben, a román határtérségből érkező mozgások egyik meghatározó céltelepülésévé Gyula (és részben Békéscsaba) vált az elmúlt két évtized során. Ennek oka a város megerősödő szolgáltatószerepkörében rejlik (pozitiv tényezők), illetve a határ román oldalán a meghatározó térszervező centrumok hiányának, nagy távolságának, nehézkes elérhetőségének tudható be (negatív tényezők).

A gazdasági fejlődés a rendszerváltást követően Romániában - még erőteljesebben, mint Magyarországon - a nagyvárosokra és közvetlen környezetükre koncentrálódott, miközben a rurális terekben stagnálás volt megfigyelhető, vagy a korábbi struktúrák leépülése zajlott. E kontextusban, a lokális szintre kon-

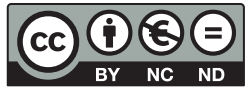


centrálva, Gyula relatív elönye még nőtt is a határ túloldalával összevetve (amit a 2008-ban kirobbant gazdasági válság tartósított). A kulcsszereplőknek a tanulmányban összesített reakciói jelzik, hogy a város képes a határ menti fekvésből, létből előnył kovácsolni, és azt saját hosszú távú stratégiái elemévé tenni.

Gyula és a határ túloldalán fekvő hajdani vonzásterület együttmúködésének sajátos eleme, hogy a nemzetiségi arányok alakulása kevéssé zavarja, sokkal gyakoribbak a magyar-román közös akciók, mint a magyar-magyar vagy a román-román kapcsolatok. Éppen erre alapozva kockáztathatjuk meg a feltételezést, hogy a város határon átnyúló szerepkörei hosszabb távon is fennmaradnak sőł erősödhetnek, nem függetlenül a nemzeti szintű és a lokális politikai folyamatok alakulásától.

KEYWORDS: borderland studies, functional urban region, cross-border activities, changing meaning of border, Hungarian-Romanian co-operations

ABSTRACT: The INNOTARS Varoster research programme (2009-2011), supported by the National Office for Research and Technology, was conducted by two Departments of the Centre for Regional Studies (Békéscsaba and Budapest) and focused on Functional Urban Regions (FUR) along the national borders in the Carpathian Basin. Seven field studies were carried out to investigate the forming and development of cross-border urban regions, the leading forces of the process, the periods of co-operations after the transition (1989-1990) and the phases of changing meanings of borders between Hungary and the surrounding countries.

In the case study area - Gyula (33,000 inhabitants) at the Hungarian-Romanian border - a questionnaire was used to ask the inner-city retailers and service providers about the importance of foreign customers, particularly Romanians, and the effects of tourism. We also tried to define the role of foreign customers of the out-of-city large-scale retail units, the local market and the thermal spa. In parallel, we conducted structured and semi-structured interviews with the key actors of the local society and economy about their activities across the Hungarian-Romanian border. To counter-check the opinions of local agents, we made 25 separate interviews on the Romanian side of the border, mainly in Oradea (205,000 inhabitants) and Arad (169,000 inhabitants) to understand the viewpoints of potential partners.

The pattern of interactions we were able to draw was unbalanced, particularly between Gyula and the smaller villages and towns that lay on the Romanian side of the border. The major part of Hungarian cross-border activities was concentrated on such centres as Arad and Oradea, and, to a lower degree, Salonta (10,000 inhabitants), as it is the terminal station of a railway that crosses the border. A certain part of activity of Hungarian actors was generated inside Transylvania, where the Hungarian minority is concentrated. Nevertheless, the primary target for Romanians crossing the border became Gyula (and, for some functions, Békéscsaba) after the transition. The reason could be found in the strengthening service functions of the town and the absence of other medium-sized Hungarian urban centres and the short distance from the large cities on the Romanian side of the border zone.

The existing differences in the level of economic development around 2000 were reduced owing to the dynamic growth of the western border zone of Romania, on the one hand, and the slow growth rate of Békés County and the whole Eastern border zone of Hungary, on the other hand. The fast economic restructuring process in Romania was concentrated in the large urban centres and their surroundings (urban regions), while in the rural areas the dominant economic process was demolishing the pre-transition structures. In this context, the relative distance in the level of economic development between Gyula and villages on the other side of the border became more pronounced, a process that was stabilised by the global economic crisis after 2008. 
The key actors of Gyula understood the importance of cross-border connections. As a consequence, there is a wide range of activities to strengthen co-operations with Romanian partners in self governments, institutions, civic organisations and enterprises. The most interesting element of that situation is the role of cross-border issues in the strategic documents of the towns and this small region.

The specific feature of the co-operation between Gyula and its traditional urban region - laying on the Romanian side of the border - is that it works independently from national origins. We saw more often Hungarian-Romanian common interactions than Hungarian-Hungarian ones (there is a large Hungarian minority living in the target area), or even Romanian-Romanian ones (Gyula is the centre of the Romanian minority in Hungary). As a conclusion we can say, this phenomenon should be further utilised as a strong basis of cross-border co-operations, regardless of local and national political debates.

\section{A kutatás háttere}

Az NKTH/NIH ${ }^{1}$ által támogatott kutatás (Innotárs_08²) keretében 2009-től kezdődően az MTA RKK Békéscsabai Osztálya és a Településkutató Osztály (Budapest) munkatársai komplex vizsgálatot indítottak a határon átnyúló várostérségek témakörében. A városrégió, várostérség fogalmának használatakor a város és környéke funkcionális összetartozásából indultunk ki, elvetve a döntően térbeli koncentrációval, technikai paraméterekkel operáló agglomeráció fogalmát, illetve a lakosság, a gazdasági tevékenységek stb. dekoncentrációját fókuszba emelő urbánus-szuburbán tér értelmezését egyaránt. A tanulmány keretében a funkcionális városi térségnek (FUA) és a funkcionális városrégiónak (FUR) azt az értelmezését fogadtuk el, amelyet az ESPON 1.1.2. (2006) és 1.4.1. kutatás (2006) zárójelentése, Faragó Lászlónak (2008) a hazai várospolitika kialakítását célzó írása, illetve részben Pálné Kovács Ilonának (2010) kutatásindító elméleti felvezetője használt.

A kutatás főbb csomópontjai:

- a városrégió megjelenése az európai és hazai területi kutatásokban és politikákban;

- a városrégiók lehatárolásának módszertani kérdései (figyelembe véve, hogy az eredményeket a felsőoktatásban is szeretnénk alkalmazni);

- a magyar határon átnyúló várostérségek kialakulásának, fejlődésének mozgatórugói, szakaszai, a határok átalakulásnak fázisai, terepi felmérésekkel feltárva, bevonva külső partnereket, egyetemi hallgatókat, doktori iskolásokat is.

A jelen kutatás során Gyulán 2010 nyarán egyetemi hallgatók (SZTE TTIK ${ }^{3}$ MSc és BSc település- és területfejlesztő geográfus szak) bevonásával két terepi felmérés készült. Az egyikben a belváros kiskereskedelmi és szolgáltatóegységeit kérdőív segítségével térképeztük fel a külföldi - ezen belül kiemelten a romániai - vendégforgalomra, valamint a turisztikai rendezvények hatására 
koncentrálva. A második felmérésben a nem belvárosi kiemelt kiskereskedelmi és turisztikai célpontok látogatóit próbáltuk azonosítani a rendszámok listázásával. A terepmunka mellett a város fejlesztési dokumentumainak elemzését, a beadott - kiemelten a határ menti együttműködési forrás megszerzése céljából benyújtott - pályázatok értékelését, a megvalósult fejlesztésekhez kapcsolódó korábbi kérdőívezések eredményeit, a helyi sajtó elemzését, illetve az azonosított kulcsszereplők strukturált interjú segítségével történt lekérdezését végeztük el. (Gyulán 45, kontrollként pedig a romániai oldalon - zömmel Nagyváradon és Aradon - további 25 interjút készítettünk.)

\section{Gyula és a határ}

A város mindennapjaiban a határhelyzet az első világháborút lezáró trianoni békerendszer következtében jelent meg (Scherer 1938), ám a város periferikus helyzetbe kerülésének gyökerei a 19. század második felébe nyúlnak vissza. Miközben az egyik oldalon sikeresen végbement Magyar- és NémetGyula egyesítése, valamint a rendezett tanácsi státus megszerzése és megtartása, a hozzá tartozó intézményrendszer kiépítése és működési feltételeinek biztosítása, addig a kiépülő országos vasúti hálózatban a közlekedési csomóponti szerep a megyén belül Békéscsabára került 1858-ban, a Budapest-Békéscsaba vonal megnyitásával (Scherer 1938, Frisnyák 1990). Gyula a későbbiekben egy kis kapacitású mellékvonalon keresztül csatlakozhatott a vasúti fóvonalhálózatra. Az elmaradó - elsősorban ipari - beruházások következtében a város helyi gazdasága Békéscsaba, majd Orosháza mögé szorult saját megyéjén belül (Marsi, Szabó 1975, Jalsovszky, Tomsics 1990, Nagy G., Nagy E. 2008). Már 1870-től megindult a versengés Békéscsaba és Gyula között a megyeszékhely címért és a megyei szintű funkciókért, s ebben a vetélytárs gyorsabb népességnövekedése, erősebb helyi gazdasága, áramlásicsomópont-szerepe Gyula pozícióját fokozatosan aláásta.

A megyeszékhelyszerep, s vele a megyei szintű funkciók többségének elvesztése 1950-ben következett el, a tanácsi közigazgatás bevezetésével párhuzamosan (Marsi, Szabó 1975, Timár, Velkey 2003). Békés megyében ezzel együtt sajátos funkciómegosztás alakult ki a megyeszékhely Békéscsaba és Gyula között: az utóbbi számos megyei szintű intézményt megőrzött (bíróság, ügyészség, cégbíróság, kórház stb.), amit a két város közti csekély távolság ( légvonalban $9 \mathrm{~km})$ tett lehetővé.

A trianoni határok megvonása következtében a tradicionális várostérség (Bácskai 1988, Kristó 1981) Romániához került (a Fehér- és Fekete-Körös völgyén felfelé az Erdélyi-középhegységig elnyúló rurális-kisvárosi térség), miközben a határ innenső oldalán nem sikerült új háttérterületet szervezni, 
elsősorban Békéscsaba erősödő vonzása következtében. Már a két világháború között új alapokra kellett helyezni a város fejlesztését. A termelőszektorokkal szemben a szolgáltató-szerepkörökre építkező fejlődési pályát indítottak el, amelyet 1959-től a gyógyvízre alapozó Várfürdő fejlesztése, a Vár többszöri rekonstrukciója, valamint a turisztikai rendezvények sora is megtámogatott (Marsi, Szabó 1975, Albel, Tokaji 2006). Ezzel párhuzamosan a 19. század végétől védett márkává alakult gyulai kolbász és a hozzá kapcsolódó ágazatok (állattartó üzemek, vágóhidak, húsüzemek) váltak a lokális gazdaság domináns szektorává, egyben a gazdasági térkapcsolati rendszer elsődleges szervezőjévé is.

A román megszállás (1919-1920), majd a határmegvonás (1921-1923) utáni években nőtt lényeges problémává a határ menti létből fakadó perifériahelyzet. A határok átjárhatósága a személyek és gazdasági szereplők számára 1925 és 1940 között korlátozottan volt lehetséges, bár interjúalanyaink szerint 1927 után a magyar oldalon lakó gazdák a román oldalra került földjeikre is átjártak azokat művelni. 1940-44 között - Észak-Erdély visszacsatolását követően - a személyek áramlása akadálymentesen történt, amit egy szinte hermetikus elzárkózás követett 1945 után. A Gyulán megnyitott nemzetközi határátkelő révén 1971-től a forgalom előbb korlátozottan, majd 1975-től a kishatárforgalom számára lényegesen szabadabb keretek között vált lehetővé. 1990 után fokozatosan enyhülő feltételek mellett előbb útlevéllel, majd személyi igazolvánnyal (magyar részről), illetve vízummentesen (román oldalról) lehetővé vált a személyek és áruk tömeges áramlása (Kasza 1999).

A periferikus fekvés ugyanakkor nem kizárólag negatív intézményi következményeket eredményezett. A magyarországi román kisebbség, intézményeinek, szervezeteinek megléte, később önkormányzatának kiépülése, majd a román külképviselet (főkonzulátus) megnyílása Gyulát a hazai románság legfontosabb centrumává emelte, így a határon átnyúló kapcsolatok építése szempontjából is felértékelte.

\section{A határon átnyúló kapcsolatok fejlődésének szakaszai}

1. A rendszerváltás, mindenekelőtt az 1989-es román forradalom teljesen új szakaszt nyitott a határ menti kapcsolatokban. A forradalmi események után közvetlenül kezdődo szakaszt az „illúziók kora”-ként jellemezhetjük. A két nép közötti, az országos politika által gerjesztett bizalmatlanság hirtelen eltünni látszott, különösen az önzetlen magyar segélyakcióknak köszönhetően. A tömeges áttelepülések kezdete már korábbra nyúlik vissza, nagyjából az 1985-ös „falurombolási program” (a román hivatalos kormányprogramban szisztematizálásnak nevezték) kezdetéig, amikortól magyar nemzetiségüek ezrével érkeztek az anyaországba. Az 1990-es évek végéig tartó hullám révén Békés megyében mintegy 5600 Romániából érkezett ember telepedett le, akik 
a későbbi évek-évtizedek során a határon átnyúló kapcsolatok fejlődésének katalizátorai lettek (Baukó 1999, Szenográdi 2005).

2. Az 1990-es évek során erős bizalmatlanság éledt újjá mindkét oldalról. Egyrészt a Nagy-Románia Párt, másrészt a Magyar Igazság és Élet Pártja tevékenységét kísérték a túlsó oldal kritikai megjegyzései. Ebben az időszakban elsősorban a civilek, egyházak, önkormányzatok, intézmények vezérelte kapcsolatok voltak a meghatározók. Úgy tekinthetünk e korszakra, mint a lassú épitkezés időszakára, amelyben komoly szerepet vittek a kétoldalú egyezmények, a testvérvárosi kapcsolatok, a közös bizottságok. A román oldal irányából nézve ez a bevásárlóturizmus klasszikus időszaka (Michalkó 1999 és 2004, Timár, Velkey 2003).

3. A következő szakasz 1998/99-2004 közé tehető. Az EU-tagságra való magyar felkészülés időszaka a tömeges cégalapitásokkal, a gazdasági kapcsolati hálók kiépítésével, határ menti uniós finanszírozású programok indulásával jellemezhető (Nagy I., Kugler 2004, Baranyi 2005). A magyar oldalon felhalmozódott tapasztalatokat know-how formájában továbbították a román oldalnak. Ebben a szakaszban kedvező volt a politikai konstelláció - az RMDSZ kormányzati szerepbe került, illetve fontos pozíciókat foglalt el lokális és regionális szinteken. A kilencvenes évek végétől erősödött fel a munkaerő áramlása Románia felől. Ez részben legális, részben - a határtérségben és Budapest környékén egyaránt - illegális formákat öltött. Dél-Alföldre legalább 5500-6000 - nagyobbrészt magyar származású - munkavállaló érkezett évente, elsősorban az építőiparba, illetve a mezőgazdasági idénymunkákra (Majoros 2006, Réti 2004, Németh 2009).

4. 2004-2007 - az EU-tagságra való román felkészülés időszaka - új szakaszként értelmezhető a határ menti kapcsolatok átalakulásában. Megindult a román gazdaság fejlődése, megjelent egy kifejezetten gazdag és egy szélesedő tehetős réteg ott is, ami jelentős vásárlóerő-többletként csapódik le a magyar oldal kereskedelmi, vendéglátási, turisztikai forgalmában (Hardi, Hajdú, Mezei 2009). A jogharmonizáció előrehalad, így könnyebbé válik a határ túloldalán a cégalapítás és -működtetés. A vízumkényszer eltörlését követően a határátlépés könnyebbé válik, ami egyben lehetőség a kisebb szereplők számára a kapcsolatok erőteljesebb építésére. A szakaszt a közös fejlesztési dokumentumoknak a készítése, a közös pályázatok számának és az általuk lefedett területeknek a növekedése, a mindkét oldal számára hasznot hajtó projekteknek a megvalósítása jellemzi (Timár 2007, Süli Zakar 2008, Majoros 2009, Nagy G. 2008).

5. A gazdasági válságig terjedő évek (2007-2009) a román gazdaság „aranyévei". Ekkor zajlanak az erőteljes ingatlanfejlesztések, infrastrukturális programok, felfut az országba érkező FDI állománya, miközben a román cégek nyugati aktivitása is megerősödik (Belanka, Duray 2009). E szakaszra jellemző, hogy megerősödik a verseny a romániai piacon a multik tömeges megjelenése következtében. A korszak kezdetén Magyarország a schengeni határőrizeti rendszer tagjává válik, ami átmenetileg nehezebbé teszi a határokon való átmozgást, elsősorban az áruk áramlásánál. A szakasz sajátos új vonása, hogy megjelenik a 
kereslet a magyar munkaerőre a román nagyvárosok fejlődő térségeiben (Németh 2009, Soós, Fejes, 2010, rEUsearch jelentés 2010, Nagy G. 2010).

6. 2009-2011 a globális gazdasági válság korszaka. A határon átnyúló kapcsolatok stagnálnak vagy visszaesnek, különösen a gazdasági kisszervezetek körében. A két határtérség szereplőinek körében megerősödik az egymásrautaltság, erősödnek a közös kezdeményezések a válság hatásainak tompítására. A román schengeni belépés, amelyet 2011 folyamán várunk, vélhetően lebontja az utolsó korlátokat az áramlásokban, aminek révén a határon átnyúló kapcsolatok új lendületet vehetnek.

\section{A vállalkozások, a munkaerópiac és a határ}

A magyar vállalkozások számára a rendszerváltást követő évektől csábító a romániai nagy ( 22 milliós) fogyasztópiac, de a határ túloldala román összevetésben is szegény, perifériahelyzetü, zömmel falusias, kisvárosias (Kisjenő, Nagyszalonta). Ennek okán a nyitás a távolabb fekvő nagy gazdasági centrumok - elsősorban Arad és Nagyvárad - felé irányult, illetve belső nagyközpontok (Kolozsvár, Brassó, Nagyszeben, Bukarest) koncentrált piacát látszott célszerűnek - egy-két éves sikeres működés után - megcélozni.

A gazdaság strukturális sajátosságai közé tartozik, hogy mind a magyar, mind a túloldalon hiányoznak vagy gyengék a húzóágazatok (a gépipar, az autóipar, az elektronika), amelyekben a legerőteljesebb a beszállítói hálózatok kiépülése. Ez az ágazati sajátosság a lokális (gyulai) kis- és középvállalkozásoknak nem ad valódi kiugrási lehetőséget (Kanalas, Kiss 2006, Nagy E., Nagy G. 2005). Ugyanakkor a román gazdaság fejlődése, különösen a fizetőképes fogyasztóréteg megerősödése, nagy teret adott a különböző közvetítőtevékenységekben dolgozók számára, mindenekelőtt a kis- és nagykereskedelemben (rEUsearch jelentés 2010). A másik perspektivikus területnek az építőipari kivitelezés bizonyult, a román oldalon induló infrastruktúra-fejlesztések (víz-, csatorna-, közút-, gázhálózat) nyújtottak lehetőséget a számukra.

A sikeres tevékenység alapfeltételeként az interjúalanyok kivétel nélkül a kinti bejáratott kapcsolat meglétét említették, ami egy bizalmi ember állandó foglalkoztatását, állandó jogászt, illetve kiépített politikai kapcsolatot jelentett önkormányzati szinten. Több alkalommal említették, hogy román nemzetiségű polgármesterrel (kormányoldali kötődésűvel) lényegesen könnyebb volt az együttmúködés, mert világosabbak voltak a játékszabályok (a helyi „elvárt" szponzoráció, a járulékos beruházásokban való részvétel). A feldolgozóiparban domináns a beszállítói kapcsolat, de szerény a kinti üzemalapítási aktivitás. Ez elsősorban arra vezethető vissza, hogy a gyulai feldolgozóipari cégek zöme KKV, se termelésének nagyságrendje nem elegendő, se felhalmozott tőkéje nincs nagyléptékű fejlesztéshez. 2010-ig aktívabb ágazat a mező- 
gazdaság, az élelmiszeripar, a faipar és bútorgyártás, illetve a már említett kereskedelem volt.

A román oldalról viszonylag korán megindult a munkaerő-átingázás, amely a 2000-es évtized közepén, a román gazdasági felfutás előtt érte el tetőpontját. A romániai munkavállalók száma erőteljesen csökkent 2008-hoz mérten (a munkaügyi központ becslése szerint, illetve az országos adatok alapján legalább 40\%-kal), ezen belül Dél-Alföldön a legkisebb mértékben (nagyjából 20\%-kal), vélhetően a kisebb ingázási távolság miatt. Ennek egyik oka a magyar oldalon a munkanélküliség növekedése, a helyben is elérhető olcsó munkaerő megléte. A meghatározó továbbra is a mezőgazdasági idénymunka (dinnye, cirok, meggy), míg csökkent az építőipari betanított és segédmunka jelentősége az ágazat évek óta fogyatkozó megrendelései következtében (2006 óta). Továbbra is jelentős foglalkoztatónak tekinthető a vendéglátás, a turisztikai idényhez kötötten. A gyulai vendéglátóiparban a románul beszélő munkaerő foglalkoztatása az utóbbi két év során látványosan megnőtt. Néhány esetben a román oldalról szolgáltatást (például mosatást, vegytisztítást), illetve alapanyagot (szállodai konyhára) is megrendelnek.

Voltak kísérletek a magyar munkavállalók kinti foglalkoztatására, különösen az aradi ipari parkok megnyitása és feltöltése során. Azokban az években (2007-2009) Arad strukturális munkaerőhiánnyal küzdött, elsősorban szakmunkásokra, kisebb arányban betanított munkaerőre lett volna szükség (szalag melletti munkára). A megtelepedő cégek vállalták volna a magyar munkaerő buszokkal történő ingáztatását, a nyelvi akadályok oldását magyar nyelven beszélő munkafelügyelőkkel és alsó szintű vezetőkkel, de a közeli falvakban ekkor már nem volt elég kvalifikált szakmunkás. Az átingázást fékezte az is, hogy a román oldalon az elérhető munkabérek nagysága alig haladta meg a magyar oldalon megszerezhető segélyek nagyságát, így anyagi motiváció nem volt. Gyula számára mind Arad, mind Nagyvárad távoli, az ingázás a kisjenői ipari zónába (mintegy $20 \mathrm{~km}$ ), illetve a Kürtösön megnyitott ipari parkba $(25 \mathrm{~km})$ lehet reális. Ezekben viszont az aradinál is alacsonyabbak a bérek, ami nem ösztönöz ottani munkavállalásra. A gazdasági válság a román gazdaságot is érzékenyen érintette. Ennek következtében a román bérszínvonal lassú felzárkózása a magyar keleti határtérséghez - benne az országosan legalacsonyabb béreket mutató Békés megyéhez - megállt, az olló ismételten nyílik, miközben a munkanélküliség szintje mind a magyar, mind a román oldalon emelkedett. 


\section{A romániai fogyasztók jelentősége - terepi felmérés, 2010 nyara}

Azzal, hogy Gyula vendégforgalmában a románok váltak a legnagyobb létszámú külföldről érkezett csoporttá (2009-ben megelőzve a város gyógyászati kínálatát korábban tömegesen igénybe vevő németeket), felértékelődött fogyasztási szokásaik, célpontjaik feltárása. 2010 nyarán a Szegedi Tudományegyetem nyári gyakorlatos geográfus-hallgatóinak (BSc) segítségével végeztük el a két fentebb említett felmérést Gyulán.

A városban a teljesen megújult központ mellett a Várfürdő (a Várral és a rendezvényekkel), a szintén pár éve megújult piac, valamint a Belvároson kívül fekvő kiskereskedelmi egységek voltak az idelátogatók elsődleges célpontjai. A Várfürdő vendégeinek körében a Romániából érkezett látogatók aránya 15-16\%-ra volt tehető, de a hétvégi napokon ennek dupláját is elérte. A Várfürdőben végzett interjúból kiderült, hogy az eladott jegyek alapján a romániai vendégkör jelentősége még ennél is nagyobb, egyes hétvégéken elérheti a 60-70\%-ot is. A fürdőkomplexum ezért románul tudó pénztárosokat alkalmaz és képez (alapfokú nyelvtanfolyamot kell elvégeznie az ott dolgozóknak), valamint a német mellé román és angol nyelvü tájékoztató táblákat is kihelyeztek.

A piac forgalmát csak a piaci napokon, akkor is elsősorban a délelőtti órákban emelik meg a romániai viszonteladók és egyéni vásárlók. A jelenleg

1. táblázat: A Gyulára érkező romániai rendszámú gépjármúvek térbeli megoszlása a fő desztinációk szerint

\begin{tabular}{|c|c|c|c|c|c|c|c|c|c|}
\hline \multirow[t]{2}{*}{ Dátum, napszak } & \multicolumn{3}{|c|}{ Kiskereskedelem } & \multicolumn{3}{|c|}{ Piac } & \multicolumn{3}{|c|}{ Várfürdő } \\
\hline & magya & román & $\begin{array}{c}\text { más } \\
\text { külföldi }\end{array}$ & magyar & smán & $\begin{array}{c}\text { más } \\
\text { külföldi }\end{array}$ & magya & omán & $\begin{array}{c}\text { más } \\
k u ̈ l f o ̈ l d i\end{array}$ \\
\hline 07. 08. délelőtt & 85 & 3 & 1 & 22 & 2 & 0 & 82 & 4 & 2 \\
\hline 07. 08. délután & 133 & 7 & 3 & 21 & 2 & 0 & 143 & 4 & 9 \\
\hline 07. 09. délelőtt & 156 & 6 & 3 & 170 & 6 & 1 & 108 & 13 & 0 \\
\hline 07. 09. délután & 180 & 6 & 0 & 24 & 3 & 0 & 121 & 35 & 13 \\
\hline 07. 10. délelőtt & 202 & 25 & 4 & 46 & 1 & 0 & 86 & 27 & 5 \\
\hline 07. 10. délután & 106 & 7 & 0 & 2 & 0 & 0 & 222 & 66 & 7 \\
\hline 07. 13. délelőtt & 100 & 5 & 3 & 36 & 5 & 1 & 135 & 7 & 3 \\
\hline 07. 13. délután & 141 & 12 & 2 & 14 & 1 & 0 & 148 & 7 & 4 \\
\hline 07. 16. délelőtt & 144 & 5 & 2 & 123 & 6 & 1 & 92 & 15 & 4 \\
\hline 07. 16. délután & 150 & 11 & 2 & 23 & 2 & 1 & 78 & 14 & 2 \\
\hline 07. 17. délelőtt & 193 & 16 & 3 & 22 & 1 & 0 & 147 & 56 & 4 \\
\hline 07. 17. délután & 89 & 6 & 5 & 17 & 1 & 0 & 227 & 63 & 4 \\
\hline Oszlop összesen & 1679 & 109 & 28 & 520 & 30 & 4 & 1589 & 371 & 57 \\
\hline 3 oszlop összesen & & 1816 & & & 554 & & & 1957 & \\
\hline $\begin{array}{l}\text { Arány a } 3 \text { oszlop } \\
\text { összesenhez, \% }\end{array}$ & 92,5 & 6,0 & 1,5 & 93,9 & 5,4 & 0,7 & 81,2 & 15,9 & 2,9 \\
\hline
\end{tabular}

Forrás: A terepi felmérés eredménye, 2010. 
mérhető forgalom a korábbi évek forgalmának már csak töredéke, a román ellátás javulása és a közeli békéscsabai piac elszívóhatása miatt (alacsonyabb árszint a viszonteladóknak).

\section{Romániából érkezett vásárlók a gyulai kiskereskedelemben}

A város - méretéhez, lokális és térségi fogyasztópiacához mérten - igen jelentős kiskereskedelmi hálózattal rendelkezik. A hazai láncok (COOP, REÁL, CBA) mellett időbeli sorrendben a LIDL, a PENNY, a SPAR, a TESCO, az ALDI és a JYSK is nyitott egységet, általában nagyobbat, mint ami a város méretéből következne. A megyében egyedül Gyulán van INTERSPAR, a TESCO egysége is hipermarket méretü, $s$ a többi lánc üzletei is elérik a megyeszékhelyen nyitott egységek nagyságát.

Az időben elsőként nyitott LIDL végül nem produkált értékelhető eredményt, ami vélhetően a városon belüli elhelyezkedésének köszönhető. Bár a város egyik fontos tengelyén fekszik, mely a határátkelő felől is elérhető, ezt az útvonalat a városba érkezők kevéssé veszik igénybe, így a bolt közönsége csak a helyi lakosságra korlátozódik.

Az ALDI új üzletét a Gyulát elkerülő út és a Gyula-Békéscsaba négysávos út csomópontja mellé építették, alapvetően a gépkocsival érkező vásárlóközönségre számítva. Ennek ellenére - ez a lenti adatokból is kitűnik - sem a helyi, sem a térségi, sem a romániai vásárlók körében nem népszerű, egyik napszakban, $\mathrm{s}$ a hét egyik napján sem.

A fennmaradó három egység mindegyike a Csabai úton, a Békéscsabáról a Belvárosba bevezető út mentén helyezkedik el. Viszonylag kevéssel a felmérés előtt nyílt a TESCO, kiugró népszerűségét talán ez indokolja. A Románia felől érkező bevásárlóforgalom zömét ezek az üzletek „fölözik le”, de a teljes forgalomból a romániaiak aránya minden esetben szerény, 6-8\%-ra tehető. Közvetett információkból, illetve dokumentumelemzésekből kiderült, hogy az egységek megnyitásában, az árukészlet összetételének meghatározásában a határon túlról érkező vásárlói körnek „fontos járulékos” 4 szerepet szántak. Úgy tűnik, ez a számítás be is vált, a romániai vendégek átlagos fogyasztása viszonylag magas, $\mathrm{s}$ a költésben a hazai fogyasztókhoz viszonyítva magasabb a prémiumtermékek részesedése.

A Romániából érkezett látogatói és vendégkör értékeléséhez két megjegyzést kell tenni. Egyik a bukaresti rendszámú autók magas aránya. A román szabályozás szerint a cégek által lízingelt autót - különösen a flottában vásároltakat - bukaresti rendszámmal látják el, függetlenül a vásárló tényleges lakhelyétől. Így az ottani rendszám zömében a közeli megyékből (Arad, Bihor, Hunad, Caras-Severin, Cluj) érkezetteket takarja, ám nem tudni, mi- 
2. táblázat: A vásárlók megoszlása a kiskereskedelem főbb egységei közöłt Gyulán

\begin{tabular}{|c|c|c|c|c|c|c|c|}
\hline Ország & Megye & ALDI & TESCO & SPAR & PENNY & Piac & Ôsszesen \\
\hline Magyarország & & 58 & 615 & 324 & 106 & 335 & 1438 \\
\hline \multirow[t]{12}{*}{ Románia } & Arad & 1 & 16 & 13 & 6 & 14 & 50 \\
\hline & Timis & 0 & 6 & 1 & 0 & 1 & 8 \\
\hline & Bihor & 0 & 3 & 0 & 1 & 2 & 6 \\
\hline & Hunad & 0 & 2 & 2 & 0 & 2 & 6 \\
\hline & Caras-Severin & 0 & 1 & 1 & 0 & 0 & 2 \\
\hline & Cluj & 0 & 1 & 0 & 0 & 0 & 1 \\
\hline & Bucuresti & 1 & 7 & 0 & 1 & 0 & 9 \\
\hline & Covasna & 0 & 1 & 1 & 0 & 0 & 2 \\
\hline & Sibiu & 0 & 2 & 0 & 0 & 0 & 2 \\
\hline & Gorj & 1 & 0 & 0 & 0 & 0 & 1 \\
\hline & Brasov & 0 & 1 & 0 & 0 & 1 & 2 \\
\hline & Összesen & 3 & 40 & 18 & 8 & 20 & 89 \\
\hline Szlovákia & & 0 & 0 & 1 & 0 & 0 & 1 \\
\hline Ausztria & & 0 & 2 & 1 & 0 & 0 & 3 \\
\hline Németország & & 1 & 3 & 4 & 1 & 2 & 11 \\
\hline Hollandia & & 1 & 0 & 1 & 0 & 0 & 2 \\
\hline Szerbia & & 0 & 1 & 0 & 0 & 0 & 1 \\
\hline Egyéb ország összesen & & 2 & 6 & 7 & 7 & 2 & 78 \\
\hline Mindösszesen & & 63 & 667 & 349 & 715 & 357 & 7545 \\
\hline
\end{tabular}

Forrás: A terepi felmérés eredménye, 2010.

lyen belső arányokkal. A másik, hogy a nyugat-európai rendszám nem takar automatikusan német, osztrák vagy holland állampolgárokat. Az ilyen kocsik egy része - ezt egy Debrecenben készült kiskereskedelmi felmérés adataiból tudjuk (Tömöri 2008) - a kint dolgozó romániai vendégmunkások tulajdonában lévő gépjármü, akik nyári szabadságra érkeztek haza a Partiumba, és „ruccantak át” Gyulára fürdőzni, vásárolni.

A gyulai kiskereskedelemben a hipermarketszintü üzletek számára a nyári forgalom mellett a karácsonyi bevásárlási csúcs is fontos, s ebben a román vendégkör szerepe annak ellenére is jelentős, hogy Nagyváradon és Aradon is megépültek az első bevásárlóközpontok (3, illetve 2), és megnyíltak az első hipermarketek. Az ottani árszínvonal még mintegy 10\%-kal magasabb a magyarnál, így kisebb távolság esetén jobban megéri a határon túlról is Gyulára jönni vásárolni.

Gyula kiskereskedelmi szerepét némileg leárnyékolja a közeli Békéscsaba, ahol a $82000 \mathrm{~m}^{2}$-es Csaba Center, a Stop Shop bevásárlóudvar és mellette a TESCO hipermarket erős vonzerőt gyakorol a Románia határ menti térségeiből érkezőkre. 
1. ábra: Honnan jönnek a „románok”? - A rendszámok megoszlása megyék szerint

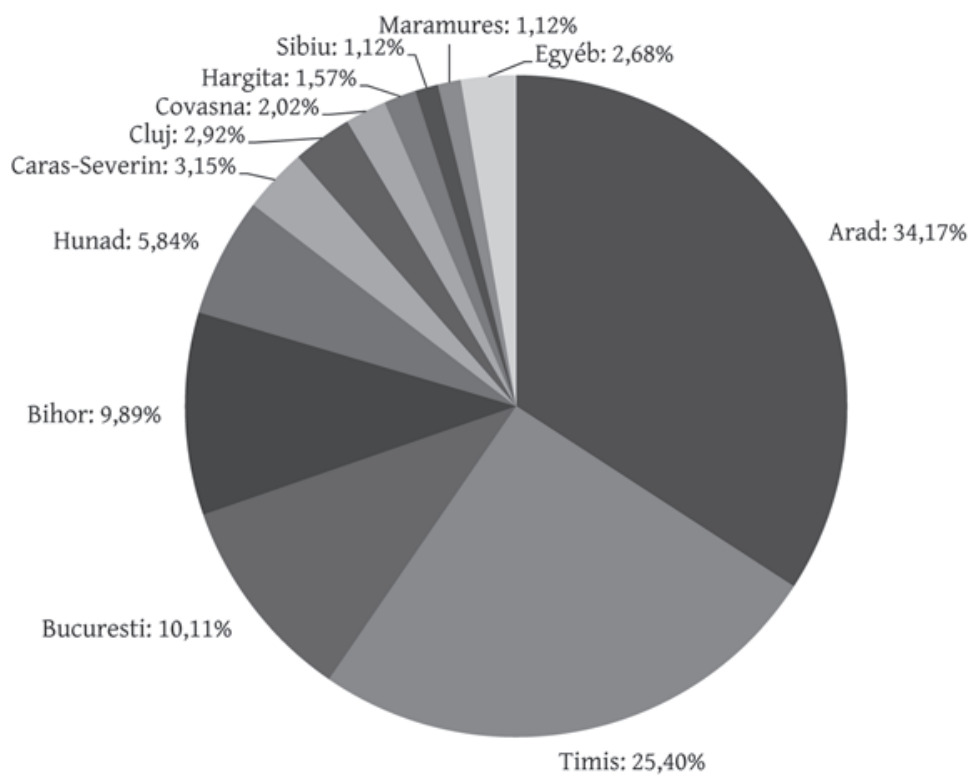

Forrás: a terepi felmérés eredménye, 2010.

\section{Fogyasztói felmérés II.: belvárosi üzletek}

A felmérés során előzetes terepbejárással lehatároltuk a Belvároshoz sorolható három fő kiskereskedelmi-szolgáltatási tömörülést, elvégeztük ennek térképezését. A kiválasztott 130 egységből a személyes lekérdezés révén 80 kérdőívet sikerült kitölteni és feldolgozni.

A külföldi vásárlók aránya az üzletek ötödében legalább a vendégkör negyedét-felét kiteszi, ennek kis hányada tekinthető visszajárónak, s az általuk generált bevétel aránya is hasonló. A romániai vásárlók aránya a külföldiek között a lekérdezett üzletek felében nem számottevő, a többiekben 25-75\% között szóródik. Gyulára meghatározóan a családosok érkeznek vásárolni.

A magyar vendégkörrel összevetve ők ugyanannyit vagy többet költenek. Több üzletben jelezték, hogy a román forgalom nélkül akár be is zárhatnának, míg a velük szomszédos vagy szemközti boltokban a romániai vendégkör érdemben meg sem jelenik. Az átlagos vásárlókhoz képest a közepes és magas árkategóriájú termékeket nagyobb gyakorisággal vásárolják, viszont egyes specializált üzletekbe - például a Hollóházi Porcelánba - lényegében be sem térnek. Az áfa-visszatérítés megszünésével (a 2007-es román EU-csatlakozás után) csökkent a Romániából érkező vásárlók száma. 
A romániai vendégek negyede-fele jól beszél magyarul, ugyanannyi töri a magyart, s több mint a fele nem tud vagy nem akar magyarul megszólalni. (A vendéglátóhelyeken készített interjúkból kiderült, hogy a román vendégek inkább nyugati nyelvtudásukat használják, nem román nyelven jelentkeznek be, függetlenül attól, hogy az adott egységben van-e románul beszélő alkalmazott.)

A belvárosi üzletek forgalmában a szezonalitás erős, a nyári hónapok a boltok fele számára kiugró bevételt jelentenek, az éven belüli második csúcsot a karácsonyi vásár időszaka jelenti számukra. A romániai forgalom mindkét csúcsban számottevő, míg a többi külföldi országból érkezettek inkább a turisztikai föszezonra koncentrálódnak. Legrosszabbnak a karácsonyt követő téli hónapokat, illetve a tavaszi és őszi hónapokat értékelik a kereskedők. Ez azt jelzi, hogy a városban zajló rendezvények, amelyek februártól decemberig tartanak, mérsékelt vásárlóerőt csábítanak. A rendezvények által generált többletforgalom zömmel a sétálóutcára korlátozódik, e tengelytől néhányszor 10 méterre fekvő boltokig a vendégek már nem jutnak el.

Sajátos, hogy a hazai kiskereskedelmi láncok üzleteiben - a megyében az Univerzál Rt. a legjelentősebb szereplő - a romániai forgalom egyáltalán nem jelentkezik. Az ottani gazdasági felfutást sem érezték meg a zömmel kisebb alapterületü üzletek, igaz, a 2008-as évtől kezdődött visszaesés sem érződik a forgalmukon.

\section{Turizmus és vendéglátás - a helyi húzóágazat}

A romániai vendégkör a legjelentősebb külföldi turisztikai célcsoporttá vált 2008-tól (vendégszám, vendégéjszakák). Jelentőségét növeli, hogy esetében magas a látogatók száma is (ők nem jelennek meg vendégként, mert nem töltenek Magyarországon egy éjszakát sem, de igénybe vesznek szolgáltatásokat, vásárolnak, étkeznek) - különösen a nyári hónapokban. A válság hatása az ő körükben is érezhető, de arányuk tovább nőtt a teljes vendégfogalomból, mert a többi célcsoportban erősebb volt a visszaesés. A távoli küldőországok esetében a megnövekedett költségek, a belföldi turisták esetében az üdülési csekk megadóztatása volt a visszaesés elsődleges oka (Albel, Tokaji 2010).

A város és az idegenforgalmi szektor reakciója példásnak mondható: román nyelvű szóróanyagok, útbaigazító táblák, információs táblák, románul beszélő személyzet beállítása (képzés), a célcsoport igényeinek felmérése és a hozzájuk való igazodás figyelhető meg. A városban folyamatos a fejlesztés, ami magában foglalja a szálláshelyek számát és minőségét, a rendezvényeket, a Várfürdő területét, illetve a városképet, hogy a hazai konkurencia (Hajdúszoboszló, Szeged) ne vonzza el a tehetős vendégkört. Proaktív reakciónak tekinthető a határon átnyúló tematikus attrakciók kialakítása, ahol a gyulai fürdoélményt romániai természeti és épített környezeti látnivalókkal egészítik ki. 
A város célzott többcsatornás marketinggel jelentkezik a fö küldőterületeken, részt vesz a turisztikai nagy kiállításokon, erőteljes a kapcsolódó szolgáltatások kiajánlása. Érdekes kezdeményezés a belső minőségi színvonal és árszínvonal garantálása (akár utcánként, tömbönként). Ezzel együtt interjúalanyaink szerint a „hólabdamódszer” több vendéget hoz, különösen a kisebb egységekbe, mint az intenzív marketingkampány.

Gyula több előnnyel is rendelkezik a nyugati országrész hasonló színvonalú fürdőivel összevetésben: a határtérség lakói számára a gyors elérhetőség kedvező, akár 2-3 napra is megéri átjönni. A magas szintű szolgáltatások, a több éve stabil árszínvonal, az egymást erősítő attrakciók (Várfürdő, Vár, rendezvények, gyógyászat) miatt a fürdőzésnél magasabb élményegyüttest lehet helyben elérni.

A romániaiakat jó vendégkörnek tartják a helybéli vendéglátóipari vállalkozások. Zömük tehetős, jól fizet, kulturált, bő felük több nyelvet beszél. Jelentős a visszajáró vendégek aránya, s nem csak a határrégióból. A gyógyturizmusban ők azok, akik a klasszikus kéthetes kúrákat tömegesen veszik igénybe, ellentétben a hazai vendégkör egyhetes turnusokra beállt forgalmával.

A megkérdezettek úgy érzékelik, hogy bár román oldalon is elindult a fürdők fejlesztése, de ez a következő 10-15 év során még nem jelent konkurenciát Gyula számára. Ennek egyik oka a Várfürdőben folyamatosan zajló és megvalósuló fejlesztésekben, más része a fürdőn kívülre tervezett élményfürdő-nagyprojektben keresendő, harmadrészt a szállodafejlesztések következménye. Gyulán 2009-ig nem volt négycsillagos szálláslehetőség, de 2012-re öt új, illetve felújított egység is eléri ezt a színvonalat, amivel ismét kísérletet lehet tenni a nyugat-európai vendégkör becsábítására.

\section{Határon átnyúló szerepkörú iskolaváros}

A város alapfokú tanintézményeinek nincs érdemi kapcsolata a román oldallal, sem intézményi, sem pályázati, sem tanulói részről. Ez alól csak a Nicolae Balcescu román nyelvű általános és középiskola tekinthető kivételnek, de az általános iskolai osztályokba a román oldalról alig érkezik diák. Középiskolai szinten a román nyelvü képzésbe a közeli határtérségből évfolyamonként 4-6 tanuló érkezik, így ez az intézmény vonzza a Romániából Gyulára érkező diákok bő felét (természetesen évente ingadozást mutatva). A kollégiumi lehetőség ellenére a beingázók zöme a közúton (Kisjenőig) és vasúton (Nagyszalontáig) jól elérhető településekről érkezik, a város hagyományos vonzásterének településeiből.

A város középfokú oktatási intézményeinek másik vonzerejét a szakmai irányú képzések adják, szakiskolai szinten a Munkácsy Mihály, szakmunkásképzésben a Harruckern János tanintézmény által kínált szakmák örven- 
denek folyamatos érdeklődésnek. Az érkező gyerekek túlnyomó része magyar nemzetiségü, hiszen a nyelvismeret elsőrendű fontosságú e képzések sikeres teljesítéséhez.

A felsőoktatásban a SZIE Egészségügyi Kar képzésein (ápolónő, szociális munkás, egészségturizmus) rendre részt vesznek Romániából érkezett hallgatók is, évfolyamonként 1-3 fö. A hallgatók kis száma miatt a beingázás térszerkezetét megrajzolni nem célszerü, de zömük északkelet felé Nagyszalonta, délkelet felé Arad által határolt területről érkezik. Az intézmény - elsősorban vezetője révén - rendkívül innovatív, számos képzési formát vezetett be elsőként az országban, tananyagfejlesztésben, illetve a határon túli kapcsolatok építésében is aktív. Utóbbi területen az aradi felsőoktatási intézményekkel és a váradi Partium Egyetemmel szoros kapcsolatok formálódtak, de az együttműködésben nem álltak meg a határtérségben, Erdély belső területein és a Székelyföldön is építettek partnerségeket.

Gyula közoktatási tanintézményeiben (az óvodai korosztályokkal együtt) a 2009-es adatok szerint 54 külföldi lakóhellyel rendelkező diák tanul, lényegesen többen, mint a nagyobb intézményhálózattal rendelkező Békéscsabán. Külföldről a megyébe legtöbben romániai lakóhellyel jönnek tanulni, közülük 48-an Gyulát választják. A határ közelsége miatt Békés megye minden városában a romániai diákok vannak többségben a külföldről érkezett tanulók között; Gyulán minden kilencedik tanuló érkezett csak más országból.

3. táblázat: A külföldi lakóhelyú diákok száma Békés megye néhány városában a közoktatási intézményekben

\begin{tabular}{|c|c|c|c|c|c|c|c|c|}
\hline \multirow[t]{2}{*}{ Küldô ország } & \multicolumn{2}{|c|}{ Békéscsaba } & \multicolumn{2}{|c|}{ Gyula } & \multicolumn{2}{|c|}{ Battonya } & \multicolumn{2}{|c|}{ Békés } \\
\hline & $\begin{array}{c}\text { lét- } \\
\text { szám, } \\
\text { fó }\end{array}$ & $\begin{array}{c}\text { arány, } \\
\%\end{array}$ & $\begin{array}{c}\text { lét- } \\
\text { szám, } \\
\text { fö }\end{array}$ & $\begin{array}{c}\text { arány, } \\
\%\end{array}$ & $\begin{array}{c}\text { lét- } \\
\text { szám, } \\
\text { fö }\end{array}$ & $\begin{array}{c}\text { arány, } \\
\%\end{array}$ & $\begin{array}{c}\text { lét- } \\
\text { szám, } \\
\text { fö }\end{array}$ & $\begin{array}{c}\text { arány, } \\
\%\end{array}$ \\
\hline Ausztria & 0 & 0,0 & 1 & 1,9 & 0 & 0,0 & 0 & 0,0 \\
\hline Németország & 0 & 0,0 & 1 & 1,9 & 0 & 0,0 & 0 & 0,0 \\
\hline Jugoszláv-utódállamok & 7 & 18,0 & 1 & 1,9 & 0 & 0,0 & 1 & 14,3 \\
\hline Románia & 25 & 64,1 & 48 & 88,9 & 7 & 100,0 & 5 & 71,4 \\
\hline Ukrajna & 1 & 2,6 & 1 & 1,9 & 0 & 0,0 & 0 & 0,0 \\
\hline Más ország & 6 & 15,4 & 2 & 3,7 & 0 & 0,0 & 1 & 14,3 \\
\hline Összesen & 39 & 100,0 & 54 & 700,0 & 7 & 100,0 & 7 & 100,0 \\
\hline
\end{tabular}

Forrás: OM-adatbázis a tanulók és hallgatók lakóhelyi megoszlásáról. 


\section{A civil szervezetek szerepe a határon átnyúló kapcsolatok fejlesztésében}

Gyula sajátos vonása, hogy már a rendszerváltás előttről nagyon mélyen beágyazott kulturális hagyományokat „örökölt” és vitt tovább. Az 1990 utáni városvezetésekben, de különösen a 2002-től induló ciklustól felerősödve világos a szándék: Gyula turisztikai vonzerejét az egész évre szétterített rendezvénysorozattal kell magasabb szintre emelni, s ezzel az idegenforgalmi idényt idöben széthúzni. Ennek érdekében a szilveszteri-újévi mulatsággal induló évad, amely a februári Reneszánsz Karnevállal folytatódik, s mintegy másfél tucat nagyobb rendezvényen át az adventi és karácsonyi programokkal zárul, tervszerüen épül egymásra. Több esetben megfigyelhető az egymást erősítő rendezvények (Pálinkafesztivál, Kézmüves Vásár, Virágok Vasárnapja, Várkerti Vigasságok, Shakespeare Fesztivál) időben is párhuzamos megtartása, hogy az eltérő vagy egymást csak részlegesen átfedő célközönségek a lehető legszélesebb társadalmi csoportokat fedjék le.

Az 1990-es évek közepétől a KBC centrumaiban (Békéscsaba, Gyula, Békés) bevett gyakorlattá vált a programnaptár előzetes egyeztetése. Így a csabai húzórendezvények (Kolbászfesztivál, Városházi Esték, Autókiállítás, Expo, illetve a békési Madzagfalvi Napok) a gyulai rendezvények közötti holtidőbe kerültek.

Ehhez képest későn, csak a 2000-es évek elején indult meg a határon túli programok erőteljesebb marketingje Gyulán, illetve az ottani programok összehangolása a gyulai kínálattal. Ezen a területen Arad és Gyula együttmüködése példaadó. A meghatározó rendezvényeken a másik város szereplői rendre megjelennek meghívottként, a programnaptárok „összefésülése” is gyakorlattá vált, így az aradi Színházi Fesztivál, illetve az Utcabál - a két leglátványosabb, legnagyobb tömeget megmozgató rendezvény - gyulai népszerűsítése, a gyulai és környéki művészek részvétele mára hagyomány lett. A két város közös INTERREG-pályázatot is nyert kulturális témában. Ezzel együtt, a további együttmüködésnek tág tere van még. A gyulai és aradi interjúink alapján tudjuk, hogy a rendezvények terén újabb pályázatok beadása várható, de tematikus turisztikai termékek kialakítására is vannak tervek: a várak bemutatása, a falusi épített örökség megóvása és bemutatása, az egyházi műemlékek megőrzése és bemutatása stb.

A sport területén az alulról jövő kezdeményezéseké az érdem. A helyi sportklubok agilis szervezői révén indult el több sportágban a kapcsolatfelvétel, s ennek eredménye közös nyári sporttáborok szervezése, játéklehetőség a másik országban, közös tornák, kupák kiírása és lebonyolítása. Eddig egyedülálló kezdeményezés kötődik a megyei labdarúgáshoz, ahol a játékvezetői kar minden évben 3-3 mérkőzésen a másik ország bajnokságában bíráskodik.

A gyulai civil szervezetek román kapcsolatai a nyelvi korlátok miatt - a határ menti fekvés és térbeli közelség ellenére - szerények. Az Erkel Művelö- 
dési Ház inkább csak helyszínt biztosít a rendezvényeknek, maga nem szervez ilyeneket. A magyar civil szervezetek elsősorban a határon túli magyar kisebbség szervezeteit keresik (például a nyugdíjasklubokat), de forrás és professzionális adminisztratív háttér hiányában ezek a kapcsolatok a legritkább esetben jutnak el közös pályázatig, megnyert projektig. Az együttműködés tartalma a kirándulásokban, közös programok szervezésében ragadható meg. A közös nyelv miatt a városban a leginkább aktívnak a román kisebbség civil szervezete tünik. Ők a határon túli román civil szféra felé a falusi térségben, de Aradon is komoly kapcsolati hálót építettek ki. Ennek folyamatos működtetése azonban forrásokat igényelne, amivel a szervezet nem rendelkezik.

Ennél is fontosabb a szerepe az Országos Román Kisebbségi Önkormányzatnak. A szervezet székhelye Gyulán található, elnöke Békés megyei származású (Battonya város alpolgármestere volt 2010-ig), így aktivitása is elsősorban a megyéhez kötődik. Az önkormányzat zömmel az oktatási, civil szféra határon túli együttműködéseit szervezi. A vezető közigazgatási tapasztalata sok esetben meghatározónak bizonyult az intézmények közötti kapcsolatépítés helyes formáinak kialakításában. Gyula esetében az önkormányzat, illetve a szintén helyben elérhető főkonzulátus támogatásával több problémás esetben sikerült az együttműködéseket magasabb szintre emelni.

\section{Egészségügy - eltéró szabályozási környezet, együttmúködési lehetôségek}

E területen három alszektort kell áttekinteni, bár ezek - kapcsolatuk tartalmát és az érintett személyi kört tekintve - erőteljes átfedésben vannak egymással. Legmagasabb szinten a Pándy Kálmán Megyei Kórház áll. A kórház vezetése szerint a Románia felől érkező betegforgalom nagyságrendje jelentős, és 2007 óta némi növekedést mutat. A Romániából érkezők ellátása a teljesítményvolumen-korlát bevezetése miatt ütemezhető, és megoldható a hazai betegek háttérbe szorítása nélkül. Egy részük a TB keretében kap ellátást (például a sürgősségi rendszeren keresztül), olyan területeken, amelyeket a román társadalombiztosítás is finanszíroz. Másik részük csak a diagnosztikai kapacitásokat veszi igénybe, amit saját maga finanszíroz. Harmadik csoportjuk rövid, meghatározóan egynapos sebészeti ellátásra, fogászati kezelésre érkezik, szintén „saját zsebre”. Egy kisszámú, de bevétel szempontjából nem elhanyagolható csoport hosszabb sebészeti beavatkozásra érkezik Gyulára (például térd- és csípőprotézismütét, illetve az azt követő rehabilitáció), ahol a román ellátás színvonala lényegesen elmarad a magyartól. Az utolsó jól definiálható kör pedig részben a magyar diagnosztika után a kint elvégzett mütéti beavatkozást követően - rehabilitációra érkezik a gyulai kórházba. 
A második alszektort az ambuláns rendelések jelentik. Ide elsősorban a magyar diagnosztikai eljárások fejlettebb színvonala miatt járnak át páciensek; különösen a korai diagnózisok pontossága miatt vonzó a magyar ellátás.

A harmadik területet a kórházban dolgozó orvosok magánpraxisaira érkező romániai páciensek jelentik. A szépészeti jellegű beavatkozások és a fentebb már említett területek mellett a nőgyógyászati, terhesgondozási profil a leginkább jellemző Gyulán.

\section{Érintetlen ingatlanpiac}

A város határ menti fekvése miatt előzetes elképzeléseink szerint a román gazdaság erőre kapásával párhuzamosan az ingatlanpiacon erősödő román befektetői, vásárlói érdeklődést valószínűsítettünk. Az előfeltevést támogatta, hogy a battonyai határátkelő közelében fekvő kisvárosok, falvak esetében megjelentek romániai vásárlók, akik részben lakást, részben hétvégi házat/nyaralót vettek, részben befektetési céllal vásároltak telket, házat, az aradinál lényegesen alacsonyabb árszinten.

Gyula esetében a helyi ingatlanpiac szereplöivel készített interjúk alapján ilyen trend nem volt kimutatható. Az 1990-es évek végén elindult egy kisebb befektetési hullám, részben ipari ingatlanokat, részben lakást vásároltak, de ez a hullám két év alatt „elcsitult”. Ennek három, egymást erősítő okát látjuk: a gyulai ingatlanok árai eleve magasak (voltak) a megyén belül. A határ túloldalán fekvő falvak romániai/partiumi összevetésben is kifejezetten szegények, onnan érdemi fizetőképes kereslet nem érkezhetett. Nagyvárad és Arad távolsága Gyulától túlzottan nagy ahhoz, hogy az ottani kereslet elérje a várost, bár ott kétségkívül van - lett volna - olyan réteg, amelynek lenne forrása (ha másból nem, a városi ingatlanból) gyulai házakat, építési telkeket venni. A közlekedési hálózat tervezett fejlesztése a romániai oldalon (Temesvár-Szatmárnémeti összekötő európai foút gyorsforgalmi célú fejlesztése), illetve a Gyula-E671-es foút összekötő szakaszának megtervezése és megépítése ezen a helyzeten változtathat néhány éven belül.

\section{Összegzés}

A kutatás során tapasztalt térfolyamatok erős egyoldalúságot mutattak Gyula város, illetve a román oldalon elterülő községek viszonylatában. A magyar oldalról történő átmozgás döntően nem a határ közvetlen közelében fekvő kistelepülésekre irányul (kivétel talán Nagyszalonta/Salonta), hanem erősebben a határhoz közeli partiumi nagyvárosokba - elsődlegesen Nagyváradra és 
Aradra -, illetve Erdély belső, magyarlakta területei felé. Ezzel szemben a román határtérségből érkező mozgások egyik meghatározó céltelepülésévé Gyula (és részben Békéscsaba) vált az elmúlt két évtized során. Ennek oka részint a város megerősödő szolgáltató szerepkörében kereshető (pozitív tényezők), részben a határ román oldalán a meghatározó térszervező centrumok hiányának, nagy távolságának, nehézkes elérhetőségének tudható be (negatív tényezők).

Az 1990-es évek végéig meglévő gazdasági fejlettségbeli különbségek (például az egy főre jutó GDP tekintetében) az utóbbi évtizedben lényegesen mérséklődtek, köszönhetően egyrészt a román oldal dinamikus gazdasági fejlődésének, másrészt Békés megye - és tágabban a keleti határrégió - vontatott dinamikájának a magyar oldalon. Ugyanakkor a gazdasági fejlődés Romániában - még erőteljesebben, mint Magyarországon - a nagyvárosokra és közvetlen környezetükre koncentrálódott, miközben a rurális terekben stagnálás volt megfigyelhető, vagy a korábbi struktúrák leépülése zajlott. E kontextusban, a lokális szintre koncentrálva, Gyula relatív előnye még nőtt is a határ túloldalával összevetve (amit a 2008-ban kirobbant gazdasági válság tartósított).

A város majd minden lényeges szereplőcsoportja felismerte a határon átnyúló kapcsolatok fontosságát Gyula további fejlődése szempontjából. Ennek köszönhető, hogy mind az önkormányzat, mind az intézmények, vállalkozások és civil szervezetek szintjén erős aktivitás látható a határon átnyúló együttműködések erősítésére, ami például a pályázati aktivitásban is megtestesül. A tanulmányban korábban említett - részben proaktív - reakciók az egyes kulcsszereplők részéről azt jelzik, hogy a város képes a határ menti fekvésből, létből előnyt kovácsolni, és azt saját hosszú távú stratégiái fontos elemévé tenni.

Gyula és a határ túloldalán fekvő hajdani vonzásterület együttműködésének sajátos eleme, hogy a nemzetiségi arányok átalakulása kevéssé zavarja, sokkal gyakoribbak a magyar-román közös akciók, mint a magyar-magyar vagy a román-román kapcsolatok, bár utóbbi kettőre is találunk példát (alapfokú oktatás, nyugdíjasklub). Éppen e jelenségre alapozva kockáztathatjuk meg a feltételezést, hogy a vizsgált város határon átnyúló szerepkörei hosszabb távon is fennmaradnak, illetve erősödhetnek, természetesen nem függetlenül a nemzeti szintű és a lokális politikai folyamatok alakulásától.

\section{Jegyzetek}

1 Nemzeti Kutatási és Technológiai Hivatal; Nemzeti Innovációs Hivatal.

2 Innotárs_08-2-2009-0036; OMFB 00972/2009. „Határtalan várostérségek - Az országhatárokon átívelő várostérségi kapcsolatok a Kárpát-medencében"

3 Szegedi Tudományegyetem, Természettudományi és Informatikai Kar.

4 A kifejezést a gyulai INTERSPAR-egység vezetője használta egy telefoninterjú során. 


\section{Irodalom}

Albel A., Tokaji F. (2006): Alföld Spa. Gyógyítás és wellness a Dél-Alföld termálfürdőiben. Dél-Alföldi Gyógy- és Termálfürdők Egyesülete, Gyula

Albel A., Tokaji F. (2010): Turizmus a Dél-Alföldön. A turisztikai régió 12 éve: 1998-2010. Az Alföld Turizmusáért - Dél-alföldi Gyógy- és Termálfürdők Közhasznú Egyesülete, Gyula

Baranyi B. (szerk.) (2005): Az Európai Unió külső határán. Együttmúködések Magyarország keleti államhatárai mentén. MTA RKK, Debrecen

Baukó T. (szerk.) (1999): Az Alföld a XXI. század küszöbén. Nagyalföld Alapítvány, Békéscsaba

Belanka Cs., Duray B. (szerk.) (2009): Helyünk a világban - alföldi válaszok a globalizáció folyamataira. MTA RKK ATI, Békéscsaba

ESPON 1.1.2. (2006): Urban-rural Relations in Europe. Final Report. Helsinki

ESPON 1.4.1. (2006): The Role of Small and Medium Sized Towns (SMESTO). Final Report. Wien

Faragó L. (2008): A funkcionális városi térségekre alapozott településhálózat-fejlesztés normatív koncepciója. Falu-Város-Régió, 3., 27-31.

Frisnyák S. (1990): Magyarország történeti földrajza. Tankönyvkiadó, Budapest

Hardi T., Hajdú Z., Mezei I. (2009): Határok és városok a Kárpát-medencében. MTA RKK, Győr-Pécs

Jalsovszky K., Tomsics E. (1992): A tegnap világa - Magyarországi városok a századfordulón írásban és képben. Officina Nova Kiadó, Budapest

Kanalas I., Kiss A. (szerk.) (2006): A perifériaképződés típusai és megjelenési formái Magyarországon. MTA RKK ATI, Kecskemét

Kasza S. (sorozat föszerk.) (1999): Békés Megye Kézikönyve. (Magyarország Megyei Kézikönyvei; 3.) Oktinfó-Szeged Bt.-CEBA Kiadó, Budapest-Szeged

Majoros A. (2006): Verseny és Együttmúködés. Magyarország és Románia külgazdasági kapcsolatainak nemzetgazdasági és regionális dimenziói. (Műhelytanulmány; 22.) Európai Összehasonlító Kisebbségkutatások Közalapítvány. EÖKIK, Budapest

Majoros A. (2009): A többszintü területi együttmüködés lehetöségei és akadályai. A Duna-Körös-Maros-Tisza Eurorégió esete. (Mühelytanulmány; 28.) Európai Összehasonlító Kisebbségkutatások Közalapítvány. EÖKIK, Budapest

Marsi Gy., Szabó F. (szerk.) (1975): Három szabad évtized Gyulán 1944-1974. Városi Tanács, Gyula

Michalkó G. (1999): A városi turizmus elmélete és gyakorlata. MTA FKI, Budapest

Michalkó G. (2004): A bevásárlóturizmus. (A turizmus termékei; 1.) Kodolányi János Főiskola, Székesfehérvár

Nagy E. (2010): A román-magyar határ menti együttműködések megítélése a román oldali településvezetők szemszögéből. Tér és Társadalom, 4., 221-236.

Nagy E., Nagy G. (szerk.) (2005): Az Európai Unió bővitésének kihivásai - régiók a keleti periférián. Nagyalföld Alapítvány, Békéscsaba

Nagy G., Nagy E.: Városok gazdasági potenciálja. A településhálózat-fejlesztés politika megalapozása a gazdaság oldaláról. Falu-Város-Régió, 3.; 32-42.

Nagy G. (2011): A gravitációs modell felhasználásának lehetőségei a várostérségek lehatárolásában. Területi Statisztika (közlésre elfogadva)

Nagy G. (kötetszerk.) (2009): Dél-Alföld. (A Kárpát-medence Régiói; 10.) (sorozatszerk.: Horváth Gy.) MTA RKK - Dialóg Campus Kiadó, Pécs-Budapest

Nagy I., Kugler J. (szerk.) (2004): Lehet-e három arca e tájnak? Tanulmányok a délkeleti határrégió újraszerveződő kapcsolatairól. MTA RKK, Békéscsaba-Pécs

Nagy, G., Nagy, E., Timár, J. (2011): The changing meaning of core-periphery relations of a non-metropolitan 'urban region' at the Hungarian-Romanian border. disP - The Planning Review Publication Forum of Network City and Landscape (under revision) 25. p.

Nagy, G. (2008): Regional planning and cooperation in practice in Danube-Cris-Maros-Tisa Euroregion. In: I. Süli-Zakar (ed.): Neighbours and Partners: on the two sides of the border. Kossuth Egyetemi Kiadó, Debrecen 
Németh N. (kutatásvez.) (2009): A román állampolgárságú munkavállalók magyarországi jelenlétének vizsgálatáról. Gyulai esettanulmány. OFA K-2007/D. MTA KTI - Genius Loci Alapítvány, Budapest, 2009. május, Kézirat, 193-221.

Pálné Kovács I. (2010): Városi terek kormányzása és városi rezsimek. Egy induló kutatás margójára. Tér és Társadalom, 4., 3-28.

Réti T. (szerk.) (2004): Közeledő régiók a Kárpát-medencében. Dél-Szlovákia, Erdély és a Vajdaság gazdasági átalakulása. Európai Összehasonlító Kisebbségkutatások Közalapítvány. EÖKIK, Budapest

rEUsearch (2010): Az Európai Unióhoz való csatlakozás hatása a határon átnyúló kapcsolatokra, agráriumra és kereskedelemre. Kutatási tanulmánykötet. Innoratio Kutatóműhely - Szórvány Alapítvány, Szeged-Temesvár

Scherer F. (1938): Gyula város története. I. kötet - A földesúri város.; II. kötet. A rendezett tanácsú város Gyula M. Város kiadása

Soós E., Fejes Zs. (szerk.) (2010): Régió a hármashatár mentén. Szeged

Süli-Zakar I. (szerk.) (2008): Neighbours and Partners: On the two sides of the border. Kossuth Egyetemi Kiadó, Debrecen

Szenográdi P. (2005): A Romániából Békés megyébe áttelepült személyek társadalom-földrajzi vizsgálata, különös tekintettel az értelmiségiekre. Doktori ( $\mathrm{PhD}$ ) értekezés. DE TTK, Debrecen

Timár J., Velkey G. (szerk.) (2003): Várossiker alföldi nézőpontból. MTA RKK ATI - MTA TKK, Békéscsaba-Budapest

Timár J. (szerk.) (2007): Határkonstrukciók magyar-szerb vizsgálatok tükrében. MTA RKK ATI Békéscsabai Osztály, Békéscsaba 